\title{
Nucleoli and AgNORs in Hodgkin's disease
}

\author{
N N Mamaev, N V Medvedeva, V F Shust, A B Markochev, N D Pasternak
}

\begin{abstract}
Aim-To evaluate the morphofunctional characteristics of lymph node cells from patients with Hodgkin's disease by measuring silver stained nucleolar organiser regions (AgNORs).
\end{abstract}

Methods-Nucleoli in Hodgkin's and Reed-Sternberg (HRS) cells, lymphocytes and prolymphocytes were investigated in cytological smears and histological sections of lymph nodes from 32 patients with Hodgkin's disease, and from 34 patients with reactive lymphadenopathy. According to the Rye histological classification of Hodgkin's disease, three cases were the lymphocyte predominant (LP) type, 14 the nodular sclerosing (NS) type, and 15 the mixed cellularity (MC) type. The investigation was done before treatment, by means of a one step silver staining method. In each case, 50 to $100 \mathrm{HRS}$ cells, lymphocytes, and prolymphocytes were evaluated to determine the mean numbers of nucleoli and AgNORs per nucleus. The nonparametric Wilcoxon Mann-Whitney test was used to compare the groups.

Results-The mean numbers of nucleoli and AgNORs were higher in lymphocytes and prolymphocytes compared with those from reactive lymph nodes used as controls. Numbers of nucleoli and AgNORs were higher (not significant) in the NS type of Hodgkin's disease than in the MC type. There was a significant increase in numbers of nucleoli in HRS cells, and their AgNOR counts were increased. The greatest number of nucleoli in HRS cells was found in the NS type. Furthermore, the nucleolar activity of HRS cells was greater in the NS type compared with the MC type (50.2 (SEM 3.9) $v$ (27.7 (2.9) AgNORs per nucleus $(p=0.025)$ ). Comparative analysis of cytological and histological samples showed that the AgNOR score was significantly higher in touch imprints than in tissue sections with tumours of the same histological type.

Conclusions-Assessment of cell activity in Hodgkin's disease patients by silver staining is more convenient and informative in lymph node imprints than in histological sections. The highest expression of interphase ribosomal RNA cistrons found in NS HRS cells is probably explained by their high proliferative activity and elevated production of transforming growth factor 1 which is known to be the most potent cytokine present in the NS subtype of Hodgkin's disease.

(F Clin Pathol: Mol Pathol 1997;50:149-152)

Keywords: nucleoli; nucleolar organiser regions; Hodg kin's disease; silver staining

The quantity of interphase silver stained ribosomal RNA cistrons in most cells has been shown in recent works to reflect directly their proliferative potential, ${ }^{1-5}$ the degree of nucleolar ploidy, ${ }^{6-8}$ and general cellular function. ${ }^{9}$ On this assumption, several investigations were carried out in malignant lymphomas, ${ }^{10-17}$ including Hodgkin's disease. ${ }^{18}{ }^{19}$ Tsenga et $a l^{19}$ have demonstrated a significant difference in the mean numbers of silver stained nucleolar organiser regions (AgNORs) per neoplastic cell among different histological types. According to these findings the lymphoid predominant (LP) type is characterised by lower AgNOR scores than the other types $(P<0.05)$. The highest AgNOR numbers were found in the lymphocyte depleted type followed by the nodular sclerosing (NS) and mixed cellularity (MC) types. The aim of the present study was to evaluate the morphological characteristics of lymph node cells from Hodgkin's disease patients by measuring AgNORs in tissue sections and lymph node imprints.

\section{Patients and methods}

Tissues from 32 untreated Hodgkin's disease patients ( 20 men and 12 women) aged between 17 and 73 years were investigated. Thirty four patients with reactive lymphadenopathy were used as controls. The diagnosis of Hodgkin's disease was made on the basis of routine histological study; according to the Rye histological classification, three cases were lymphocyte predominant (LP), 14 were nodular sclerosing (NS), and 15 were mixed cellularity (MC) type. The stages, according to the Ann Arbor classification, were four in IIa, seven in IIIA, 17 in IIIB, and four in IVB.

Sixty six lymph node touch imprints and 20 lymph node biopsy specimens were studied. Imprints were dried at room temperature, fixed in methanol/acetic acid (3:1), rinsed thoroughly with distilled water, and air dried repeatedly. These were put into $2 \mathrm{~N}$ formic acid for 10 minutes to reduce the egress of silver from the nucleoli, and, to facilitate the measurement of nucleoli and AgNORs, rinsed again and impregnated with silver nitrate.

The biopsy specimens were fixed in $10 \%$ neutral buffered formalin and embedded in paraffin wax. Sections $(5 \mu \mathrm{m})$ were taken to 
Table 1 Clinical findings and nucleolar silver staining data from patients with different histological subtypes of Hodgkin's disease. Values are means (SEM)

\begin{tabular}{|c|c|c|c|c|c|}
\hline \multirow[b]{2}{*}{ Histological types } & \multirow[b]{2}{*}{$\begin{array}{l}\text { Patients } \\
\text { (No) }\end{array}$} & \multirow[b]{2}{*}{$\begin{array}{l}\text { Patients in different clinical stages } \\
\text { (No) }\end{array}$} & \multicolumn{3}{|c|}{$\begin{array}{l}\text { Number of nucleoli (above) } \\
\text { Number of AgNORs (below) }\end{array}$} \\
\hline & & & $\begin{array}{l}\text { Lymphocytes and } \\
\text { prolymphocytes }\end{array}$ & $H R S$ cells & $p$ \\
\hline Lymphocyte predominant & 3 & IIA-1; IIIA-2 & $\begin{array}{l}1.07(0.03) \\
5.77(0.30)\end{array}$ & $\begin{array}{r}3.03(0.88) \\
32.39(5.56)\end{array}$ & \\
\hline Nodular sclerosing & 14 & IIIA-4; IIIB-8; IVB-2 & $\begin{array}{l}1.32(0.06) \\
7.85(0.55)\end{array}$ & $\begin{array}{r}7.85(0.55) \\
50.2 \quad(3.90)\end{array}$ & \\
\hline Mixed cellularity & 15 & IIA-3; IIIA-1; IIIB-9;IVB-2 & $\begin{array}{l}1.21(0.06) \\
7.42(0.30)\end{array}$ & $\begin{array}{r}3.11(0.23) \\
37.7(2.90)\end{array}$ & 0.025 \\
\hline
\end{tabular}

HRS = Hodgkin's and Reed-Sternberg cells.

* Statistical significance between the nodular sclerosing and mixed cellularity histological subtypes-Wilcoxon Mann-Whitney test.

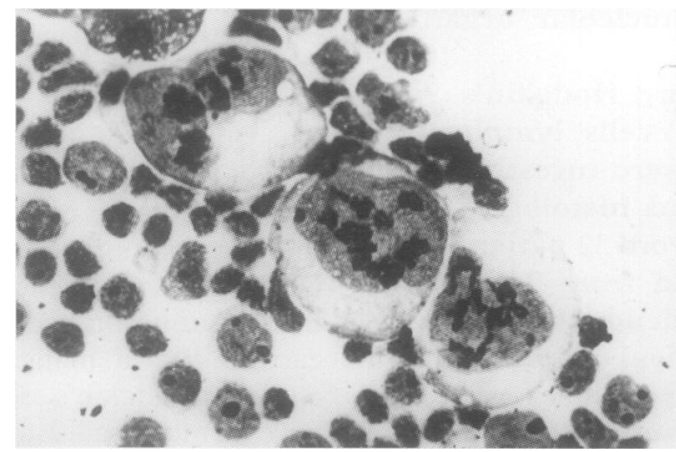

Figure 1 Silver-stained Hodgkin's and Reed-Sternberg cells in lymph node imprints from a patient with Hodgkin's disease (original magnification $\times 1000$ ).

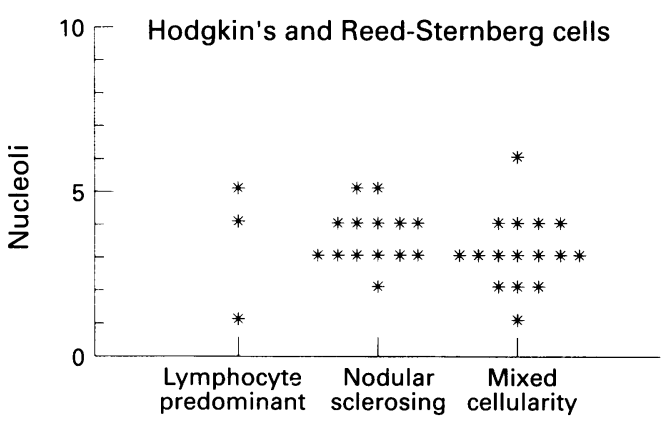

Histological types of Hodgkin's disease

Figure 2 The mean number of nucleoli in Hodgkin's and Reed-Sternberg cells in lymph node imprints from patients with different histological subtypes of Hodgkin's disease.

water via xylene and graded alcohols. These were put into $2 \mathrm{~N}$ formic acid for 10 minutes, rinsed, air dried and impregnated with a mixture of $50 \%$ aqueous solution of silver nitrate with gelatin at $68^{\circ} \mathrm{C}$ for four minutes (after Howell and Black $^{20}$ with slight modification $\left.^{5}\right)$. The silver colloid was then washed off with distilled, de-ionized water. The preparations were lightly counterstained with $2 \%$ Giemsa for 20 seconds, dehydrated through the graded ethanols to xylene and mounted in synthetic medium.

In each case, the mean numbers of nucleoli and AgNORs per nucleus were counted in 50 to 100 Hodgkin's and Reed-Sternberg (HRS) cells, lymphocytes, and prolymphocytes using an oil immersion lens at a magnification of $\times 1000$ or $\times 1200$. Student's $t$ test and nonparametric Wilcoxon Mann-Whitney tests were used to compare the patient and control groups.
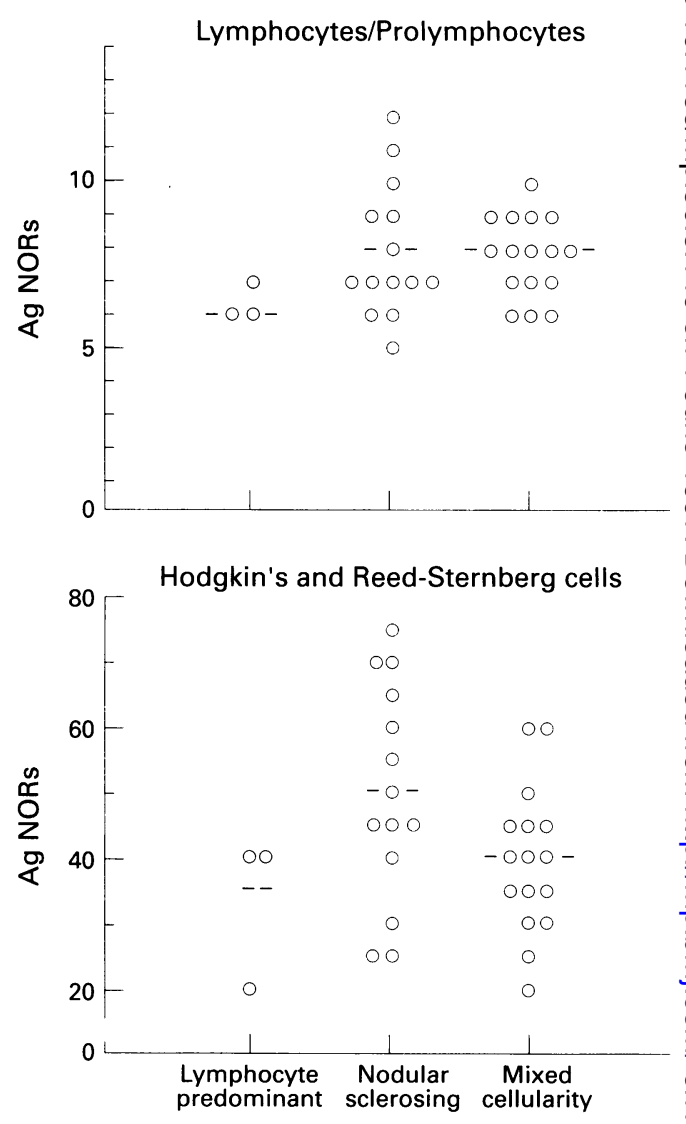

Histological types of Hodgkin's disease

Figure 3 The average numbers of AgNORs in prolymphocytes, lymphocytes and Hodgkin's and Reed-Sternberg cells in lymph node imprints from patients with different histological subtypes of Hodgkin's disease.

\section{Results}

Clinical findings and the results of nucleolar silver staining of lymph node pathological cells from patients with Hodgkin's disease are presented in table 1 and figures 1-3.

NUMBERS OF NUCLEOLI

The numbers of nucleoli in the lymphocyte and prolymphocyte populations from Hodg- 8 kin's disease patients ranged from 1.0 to $1.92 \leftrightharpoons$ per nucleus. The mean (SEM) number of nucleoli did not differ from those in controls $(1.24(0.03) v 1.18(0.01))$. There was a slight difference in the nucleolar score in the NS and LP types $(1.32 v 1.07, \mathrm{p}<0.05)$. The numbers of nucleoli in HRS cells ranged from 1.56 to 5.33. The mean numbers of nucleoli in HRS 


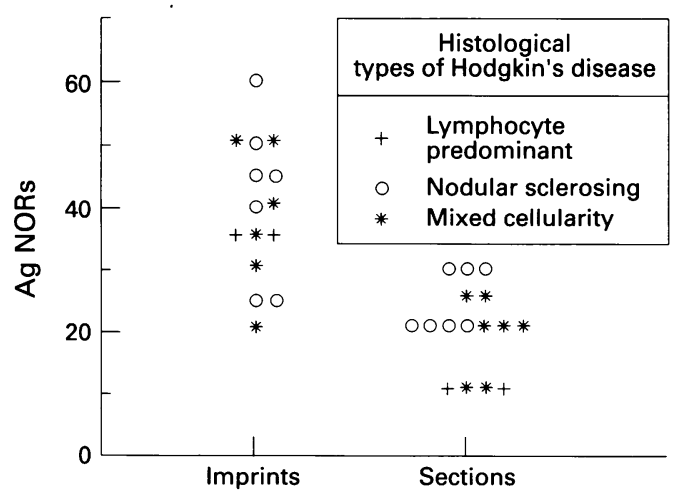

Figure 4 Comparative analysis of AgNORs in Hodgkin's and Reed-Sternberg cells in imprints and sections from patients with different histological subtypes of Hodgkin's disease.

cells were higher than in lymphocytes and prolymphocytes (3.22 (0.17), $\mathrm{p}<0.001)$. The numbers of nucleoli in the NS type were slightly higher than that in the MC type (7.8 $(0.55) v 3.11(0.23))$.

\section{AgNOR SCORES}

The AgNOR scores in lymphocytes and prolymphocytes from Hodgkin's disease patients ranged from 5.4 to 11.2 . The mean AgNOR score was similar in patients and controls. The highest mean number of AgNORs was found in the NS type. The count was intermediate in the MC type, and least in the LP type.

The AgNOR scores in HRS cells ranged from 21.6 to 74.6 per nucleus; the average number of AgNORs was highest in the NS type. The count was intermediate in the MC type and least in the LP. Analysis of variance showed a statistically significant difference between the NS and the MC types (50.2 (3.9) $v 37.7$ (2.9), $\mathrm{p}<0.025)$. The AgNOR counts were independent of the stage or the presence of B symptoms and there was no correlation with many other clinical and laboratory parameters.

HRS CELL AgNORS IN IMPRINTS AND SECTIONS The results of AgNOR comparative analysis in cytological and histological samples obtained from 16 patients with Hodgkin's disease are presented in figure 4. The AgNOR score was significantly higher in touch imprints than in tissue sections within tumours of the same histological type. Moreover, the concordance of counting between two samples from the same patient was not strong.

\section{Discussion}

This study confirmed previously reported findings of nucleolar changes in HRS cells from patients with Hodgkin's disease.$^{18}{ }^{19}$ First, HRS nucleoli were larger and more polymorphic compared with those in lymph node lymphocytes and prolymphocytes from the same patient. Second, the numbers of AgNORs in HRS cells were higher in the NS type than in the MC and LP varieties. Interestingly, a similar conclusion was made previously in an investigation of histological sections. ${ }^{19}$ The changes are clearer, however, in imprints than in sections. In the previous study low AgNOR indices were seen only in the LP type $(p<0.05) .{ }^{19}$ On the contrary, the difference between AgNOR counts in the NS and MC types was not significant (3.24 (1.41) $v 2.63$ (0.93)). In general, these and our results show that the AgNOR scores in HRS cells may be related to the histological type of Hodgkin's disease; however, the scores are independent of the stage or the presence of B symptoms, and there is no correlation with most other clinical and laboratory parameters. It is noteworthy that the HRS proliferative rate measured by proliferative cell nuclear antigen, $\mathrm{Ki}-67$, and c-myc p62 oncoprotein expression was comparatively high, while the difference between various histological types was not statistically significant. In addition, there was no correlation with AgNOR counts of HRS cells. ${ }^{19}$ However, we did notice that the previous results of HRS proliferative rate agreed with our findings of increased AgNOR counts in the NS type. As shown by Tsenga $e a^{19}$ the percentage of HRS cells stained by PC-10 and Ki-67 antibody was slightly higher in the NS type compared with the MC type. Furthermore, the expression of c-myc p62 oncoprotein was also higher in the NS type of Hodgkin's disease than in the MC and LP varieties. Conversely, a recent investigation showed that the mean mitotic state and other kinetic indices of HRS cells were higher in the MC than in the NS type of Hodgkin's disease. ${ }^{21}$ According to these findings, these cellular parameters were associated with higher DNA fragmentation (related to apoptosis) and the presence of many abortive mitoses in HRS cells. As a result, the percentage of $\mathrm{Ki}-67$ positive HRS cells in Hodgkin's disease did not correlate significantly with their mitotic indices.

Evidence of relatively high ribosomal cistron activity in HRS cells from patients with Hodgkin's disease may be explained partly by their high proliferative potential as well as increased nuclear ploidy. The higher AgNOR counts in HRS cells in the NS variant of Hodgkin's disease may be explained as follows: HRS cells from patients with Hodgkin's disease can produce several cytokines both in vitro and in vivo including IL-1, IL-3, IL-4, IL-5, IL-6, IL-8, IL-9, GM-colony stimulating factor (CSF), tumour necrosis factor (TNF) $-\alpha$, TNF- $\beta$, and transforming growth factor $\beta$ (TGF-1) ${ }^{22}$ Most of these cytokines were activated in all histological subtypes of Hodgkin's disease; however, TNF was more readily detected in the cell line established from a patient with the NS type than that from a patient with the MC type. ${ }^{23}$ TGF-1 was found to be greatly activated only in the NS type of Hodgkin's disease. ${ }^{24-28}$ As the main sources of TGF in the lymph nodes of patients with the NS type of Hodgkin's disease were mononuclear Hodgkin's cells, some Reed-Sternberg cells, and activated lymphocytes, ${ }^{28}$ AgNOR elevation in the NS type HRS cells may be related to increased cytokine production.

In conclusion, comparison of AgNOR scores in lymph node sections and imprints prepared from the same patients supported previously 
reported results that the latter were more informative for assessment of Hodgkin's disease cell activity. In our opinion, this observation may be connected with more rough fixation of histological samples inducing an increased AgNOR aggregation and problems in AgNOR examination; and the inevitable decrease of AgNOR counts in sections cut at a thickness less than the nuclear diameter.

1 Gonzalez-Guzman I. Generalities on the nucleolar content of some blood cells. Blood 1947;2:57-65.

2 Crocker J. Nucleolar organizer regions. Curr Top Pathol 1990;82:91-149.

3 Derenzini M, Pession A, Trere D. The quantity of nucleolar silver-stained proteins is related to proliferating activity in cancer cells. Lab Incest 1990;63:137-40.

4 Mamaev N, Mamaeva S. Nucleolar organizer region activity in human chromosomes and interphase nuclei of normal leukemic, and tumor cells as evaluated by silver staining. $I \mathrm{mt}$ Rev Cvtol 1990;121:233-66.

5 Mamaev NN, Mamaeva SE, Liburkina IL, Kozlova TV, Medvedeva NV, Makarkina GN. The activity of nucleolar Medvedeva NV, Makarkina GN. The activity of nucleolar
organizer regions (NOR's) of human bone marrow cells organizer regions (NOR's) of human bone marrow cells
studied with silver staining. I. Chronic myelocytic leukemia. Cancer Genet Cytogenet 1985;16:311-20.

6 Mamaev NN, Salogub GN, Koloskov AV. Interphase ribosomal RNA cistron staining in chronic myeloid leukaemia. f Clin Pathol: Mol Pathol 1995;48:M260-4.

7 Mamaev NN, Grichanova TI, Shandlorenko DS, Koloskov AV. Morphological and functional characteristics in normal and pathological megakaryocytes as evaluated by silver staining [Russian]. Gematol Transfuziol 1990;35(11):17-20.

8 Baatout S, Chatelain B, Dupret P, Staquet PH, Venkerhoven P, Symann M. Nucleolar organizer regions of megakaryocyte cell lines augment after induction of polyploidization cyte cell lines augment after induction of polyploidization

9 Mamaev NN, Mamaeva SE. The structure and function of nucleolar organizer regions (NORs): Molecular, cytological, and clinical aspects [Russian]. Tsitologiia 1992;34(10): 3-25.

10 Crocker J, Nar P. Nucleolar organizer regions in lymphomas. F Pathol 1987;151:111-8.

11 Crocker J, Hall PA, MacCartney JC, Stansfeld AG. A comparative study of nucleolar organizer regions (AgNORs), Ki67 staining and DNA flow cytometry in non-Hodgkin's Ki67 staining and DNA flow cytometry in non-

$12 \mathrm{Xu} \mathrm{LZ}$, Wang LF. Nucleolar organizer regions in aspirates of malignant lymphomas and benign disorders of the lymph nodes. Anal Quant Cytol Histol 1992;14:148-52.

13 Munkata S, Hendricks JB. Morphometric analysis of AgNORs in imprints and sections from non-Hodgkin's lymphomas. An approach to standardization. Anal Quant Cvtol Histol 1993;15:329-34.
14 Yekeler H, Ozercan MR, Yumbul AZ, Agam M, Ozercan IH. Nucleolar organizer regions in lymphomas: a quantitative study. Pathologica 1993;85:353-60.

15 Jakic-Raumovic J, Tentor D, Petrovecki M, Radman I Nucleolar organiser regions and survival in patients with non-Hodgkin's lymphomas classified by the working formulation. F Clin Pathol 1993;46:943-7.

16 Korkolopoulou P, Patsouris E, Pangalis GA, Tsenga A, Elemeneglou J, Thomas-Tsangli E, it al. A comparative assessment of proliferating cell nuclear antigen, c-myc p62, and nucleolar organizer region staining in non-Hodgkin's lymphomas: a histochemical and imunohistochemical lymphomas: a histochemical and imunohist
study of 200 cases. Hum Pathol 1993;24:371--7.

17 Smith FG, Murray PG, Crocker J. Correlation between PCNA and AgNOR scores in non-Hodgkin's lymphomas using sequential staining technique. F Clin Pathol 1993;46: $28-31$.

18 Freeman J, Kellock DB, Yu CC Crocker J, Levison DA, Hall PA. Proliferating cell nuclear antigen (PCNA) and nucleolar organiser regions in Hodgkin's disease: correlation with morphology. $\mathcal{F}$ Clin Pathol 1993;46:446-9.

19 Tsenga A, Korkolopoulou P, Patsouris E, Pangalis GA, Oates J, Skopelitou A, it al. Proliferative cell nuclear antigen, Ki-67, c-myc p62 oncoprotein, and nucleolar organizer regions in Hodgkin's disease. Applied Immumohis tochemistry 1994:2:191-6.

20 Howell WM, Black DA. Controlled silver staining of nucleolus organizer regions with a protective colloidal developer: a one step method. Experientia 1980;36:1014-5.

21 Spina D, Leoncini L, Close P, Megha T, Pacenti L, Tosi P, $\iota t$ al. Growth vs. DNA strand breaks in Hodgkin's disease: Impaired proliferative ability of Hodgkin and Reed- $\omega$ Sternberg cells. Int 7 Cancer 1996;66:179-83.

22 Gause A, Keymis S, Scholz R, Schobert I, Jung W, Diehl V, et al. Increased levels of circulating cytokines in patients with untreated Hodgkin's disease. Lymphokine Cytokinc Research 1991;11:109-13.

23 Hsu P-L, Hsu S-M. Production of tumor necrosis factor- $\beta$ and lymphotoxin by cells of Hodgkin's neoplastic cell lines HDLM-1 and KM-H2. Am f Pathol 1989;135:735-45.

24 Newcom SR, Kadin ME, Ansari AA, Diehl V The L-428 nodular sclerosing Hodgkin's cell secretes a unique TGF- $\beta$ active at physiologic pH. F Clin Invest 1988;82:1915-21.

25 Hsu S-M, Lin J, Xie S-S, Rich S. Abundant expression of transfroming growth factor- 1 and -2 by Hodgkin's and Reed-Sternberg cells and by reactive $T$ lymphocytes in Hodgkin's disease. Hum Pathol 1993;24:249-55.

26 Kadin ME, Agnarsson BA, Ellingsworth LR, Newcom SR Immunohistochemical evidence of a role for transforming growth factor beta in the pathogenesis of nodular sclerosing Hodgkin's disease. Am f Pathol 1990;136:1209-14.

27 Newcom SR, Tagra KK. High molecular weight transform ing growth factor is exreted in the urine in active nodula sclerosing Hodgkin's disease. Cancer Res 1992;52:6768-73.

28 Newcom SR, Gu L. Transforming growth factor-1 messenger RNA in Reed-Sternberg cells in nodular sclerosing Hodgkin's disease. 7 Clin Pathol 1995;48: 160-3. 